\title{
EFEKTIVITAS PERANGKAT PEMBELAJARAN IPA UNTUK MELATIHKAN KETERAMPILAN BERPIKIR KRITIS PESERTA DIDIK SMP PADA MATERI POKOK LISTRIK STATIS
}

\author{
Mutiara Havina Putri ${ }^{1^{*}}$., Fahmi ${ }^{2}$., Eko Wahyuningsih ${ }^{3}$ \\ ${ }^{1}$ Guru SMK Penerbangan, Banjarbaru, Kalimantan Selatan, Indonesia \\ e-mail: mutiara.15putri@gmail.com \\ ${ }^{2}$ Magister Keguruan IPA, Program Pascasarjana, Universitas Lambung Mangkurat, Banjarmasin, Indonesia \\ e-mail: ibnusuwandy@gmail.com \\ ${ }^{3}$ Guru IPA SMPN 1 Angsana, Kabupaten Tanah Bumbu, Provinsi Kalimantan Selatan, Indonesia \\ e-mail: ekowahyuningsih15@gmail.com
}

$\begin{array}{lll}\text { Submit } & : 11-02-2021 & \text { Revision : 22-03-2021 } \\ \text { Accepted } & : 26-03-2021 & \text { Published : 01-04-2021 }\end{array}$

*Corresponding author: Mutiara Havina Putri

\begin{abstract}
Abstrak: Penelitian ini bertujuan untuk mengevaluasi efektivitas perangkat pembelajaran materi pokok listrik statis pada peserta didik SMP. Perangkat pembelajaran meliputi silabus, RPP, materi ajar, LKPD, dan lembar penilaian. Model penelitian yang digunakan adalah model pengembangan Tessmer yang terdiri atas lima langkah yaitu: 1) Evaluasi diri (self evaluation); 2) pendapat pakar (expert review); 3) uji coba perorangan (one to one); 4) uji coba kelompok kecil (small group); dan 5) uji lapangan (field test). Teknik analisi data yang digunakan dalam penelitian ini adalah analisis kuantitatif untuk menilai efektivitas perangkat pembelajaran. Hasil penelitian menunjukkan perangkat pembelajaran yang dikembangkan dinilai efektif dilihat dari hasil LKPD yang menunjukkan tren peningkatan pada indikator keterampilan berpikir kritis.
\end{abstract}

Kata kunci: efektivitas, perangkat pembelajaran, keterampilan berpikir kritis, listrik statis

\section{THE EFFECTIVENESS OF SCIENCE LEARNING DEVICES TO TRAIN CRITICAL THINKING SKILLS OF JUNIOR HIGH SCHOOL STUDENTS IN STATIC ELECTRICITY MATERIALS}

\begin{abstract}
This study aims to evaluate the effectiveness of the static electricity subject matter learning device for junior high school students. Learning tools include syllabus, lesson plans, teaching materials, LKPD, and assessment test. The research model used is the Tessmer development model which consists of five steps, namely: 1) Self evaluation; 2) expert review; 3) one to one; 4) small group; and 5) field test. The data analysis technique used in this research is quantitative analysis to assess the effectiveness of the learning tools. The results showed that the learning tools developed were considered effective as seen from the LKPD results which showed an increasing trend in the indicators of critical skills.
\end{abstract}

Keywords: effectiveness, learning tools, critical thinking skills, static electricity

\section{PENDAHULUAN}

Pendidikan Ilmu Pengetahuan Alam (IPA) saat ini belum banyak berorientasi ke arah pembiasaan dan peningkatan kecakapan keterampilan berpikir tingkat tinggi. Padahal sejatinya melalui pembelajaran IPA peserta didik diharapkan dapat melatih keterampilan berpikir tingkat tinggi. Namun pada kenyataannya peserta didik hanya menyerap informasi secara pasif dan kemudian mengingatnya pada saat mengikuti tes (Ra- 
Putri, M.H., Fahmi., \& Wahyuningsih, E. (2021). Efektivitas Perangkat Pembelajaran IPA untuk Melatihkan Keterampilan Berpikir Kritis Peserta Didik SMP pada Materi Pokok Listrik Statis.

hayu dkk., 2018). Pembelajaran yang seperti ini mengakibatkan peserta didik tidak memperoleh pengalaman untuk mengembangkan kemampuan berpikirnya, padahal tuntutan dalam bidang pendidikan setiap tahunnya semakin tinggi (Fahmi \& Irhasyuarna, 2019).

Salah satu kemampuan yang sangat diperlukan adalah kemampuan berpikir tingkat tinggi dalam menghadapi globalisasi seiring dengan perkembangan IPTEK. Tantangannya sekarang yaitu melatihkan peserta didik untuk berpikir tingkat tinggi seperti keterampilan berpikir kritis (Fahmi dkk., 2019). Berdasarkan hasil survei PISA dari tahun 2009 sampai dengan 2018 peringkat Indonesia selalu mengalami penurunan dan mengindikasikan lemahnya kemampuan peserta didik Indonesia pada bidang sains (Kemendikbud, 2019). Hasil studi ini dapat dijadikan rujukan mengenai tingkat kemampuan sains anak-anak Indonesia dibandingkan dengan negara lain. Hal ini menjadi tantangan yang dihadapi oleh Indonesia serta negara berkembang lainnya. Oleh sebab itu berikir kritis merupakan sumber daya yang berharga dalam pengajaran (Fahmi, 2018).

Kemampuan berpikir dalam IPA berkaitan erat dengan cara mencari tahu dan memahami alam semesta secara sistematis, yang berisi konsep, teori-teori atau rumus-rumus yang harus dipahami secara mendalam. Dengan demikian, peserta didik dituntut untuk dapat berikir kritis dalam membangun pengetahuan dengan peran aktif dalam proses pembelajaran. Pada kenyataan, berdasarkan hasil observasi yang telah dilakukan di SMP Negeri 2 Bati-Bati melalui wawancara dengan pendidik IPA dan pengamatan dalam proses pembelajaran, menunjukkan proses pembelajaran dipandang hanya sebagai pentransferan ilmu, pembelajaran menjadi kurang menarik akibatnya tidak berkembangnya kemampuan bertanya dan bernalar. Soal-soal evaluasi yang diberikan belum berorientasi untuk mengembangkan kemampuan berpikir kritis peserta didik, sehingga peserta didik kurang didorong untuk mengembangkan kemampuan berpikirnya. Hal inilah yang cenderung menjadi penyebab rendahnya kemampuan berpikir kritis peserta didik.

Fahmi dan Irhasyuarna (2019) dalam bukunya mengidentifikasi beberapa permasalahan pendidikan diantaranya; (1) pendidikan lebih menekankan pada aspek kognitif dengan orientasi penguasaan ilmu pengetahuan yang sebanyak-banyaknya dan mengabaikan perkembangan aspek afeksi dan aspek konasi, (2) pendidikan kurang memberikan perkembangan keterampilan proses, kemampuan berpikir kritis, dan kreatif, (3) pendidikan kurang memberikan pengalaman yang nyata melalui pendekatan kurikulum dan pembelajaran terpadu. Perbaikan pendidikan melalui pengembangan kurikulum menurut Supervision of the Ministry of Education (MOE) dari lembaga pendidikan Taiwan, mencakup tema utama seperti literasi sains, keterampilan proses, sikap ilmiah, keterampilan berpikir, dan penerapan ilmu pengetahuan (Chang \& Chiu, 2005).

Secara umum kurikulum tidak lain merupakan seperangkat pembelajaran yang merupakan salah suatu alat penunjang keberhasilan pembelajaran dan menjadikan proses pembelajaran menjadi lebih efektif. Perencanaan perangkat pembelajaran yang baik berimbas pada pelaksanaan pembelajaran yang sukses (Ningtyas dkk., 2020; Khaerani dkk., 2020). Potensi peserta didik juga dapat diwujudkan dalam pendidikan melalui pengembangan perangkat pembelajaran (Rahmawati dkk., 2020). Hal ini sesuai dengan tujuan utama pendidikan yakni mengembangkan bakat individu, mewujudkan potensi kreatif dan inovatif, serta pencapaian tujuan serta tanggung jawab pribadi terhadap kehidupan sosial dalam masyarakat.

Pentingnya peserta didik memiliki keterampilan berpikir kritis dikarenakanan keterampilan ini memungkinkan peserta didik mampu menganalisis dan mengevaluasi informasi dalam menentukan informasi yang dapat dipercaya, sehingga bisa digunakan sebagai dasar menarik kesimpulan yang valid (Af'idayani dkk., 2018). Menurut Marie dan Emmanuelle (2011) keterampilan berpikir bukan merupakan bawaan yang dimiliki oleh peserta didik, namun keterampilan berpikir dapat dipelajari dan memerlukan belajar. Adapun indikator berpikir kritis yang diturunkan dari aktivitas kritis menurut Watson dan Glaser, (2012) seseorang bisa dikatakan mampu berpikir kritis apabila memiliki; 1) sikap inkuiri dan eksplorasi terhadap bukti yang mendukung secara akurat dan menyeluruh, 2) pengetahuan tentang kevalidan inferensi, abstraksi, dan generalisasi, dan 3) keterampilan dalam menerapkan sikap dan pengetahuan tersebut.

Berdasarkan paparkan di atas, perlu dilakukan upaya dalam proses pembelajaran untuk dapat melatihkan keterampilan berpikir kritis peserta didik salah satunya dengan memilih pendekatan pembelajaran yang tepat dan lebih berpusat pada peserta didik. Salah satu model pembelajaran tersebut adalah model discovery learning dimana dalam model ini peserta didik belajar untuk menemukan dan menemukan konsep secara mandiri (Khabibah, 2017; Fahmi dkk., 2019). Model pembelajaran discovery learning menuntut peserta didik untuk aktif, kreatif, serta inovatif untuk melibatkan ilmu pengetahuan dan keterampilan proses dalam membangun konsep, hukum atau prinsip, dan untuk melibatkan proses kognitif potensial dalam rangsangan pengembangan intelektual (Arianda, 2018). Pola pemebelajaran tersebut menujukkan bahwa 
model pembelajaran discovery learning cocok dengan pendekatan ilmiah sehingga mampu melatihkan keterampilan berpikir kritis peserta didik.

\section{METODE PENELITIAN}

Jenis penelitian ini merupakan penelitian pengembangan dengan menggunakan desain pengembangan Tessmer(Tessmer, 1998).

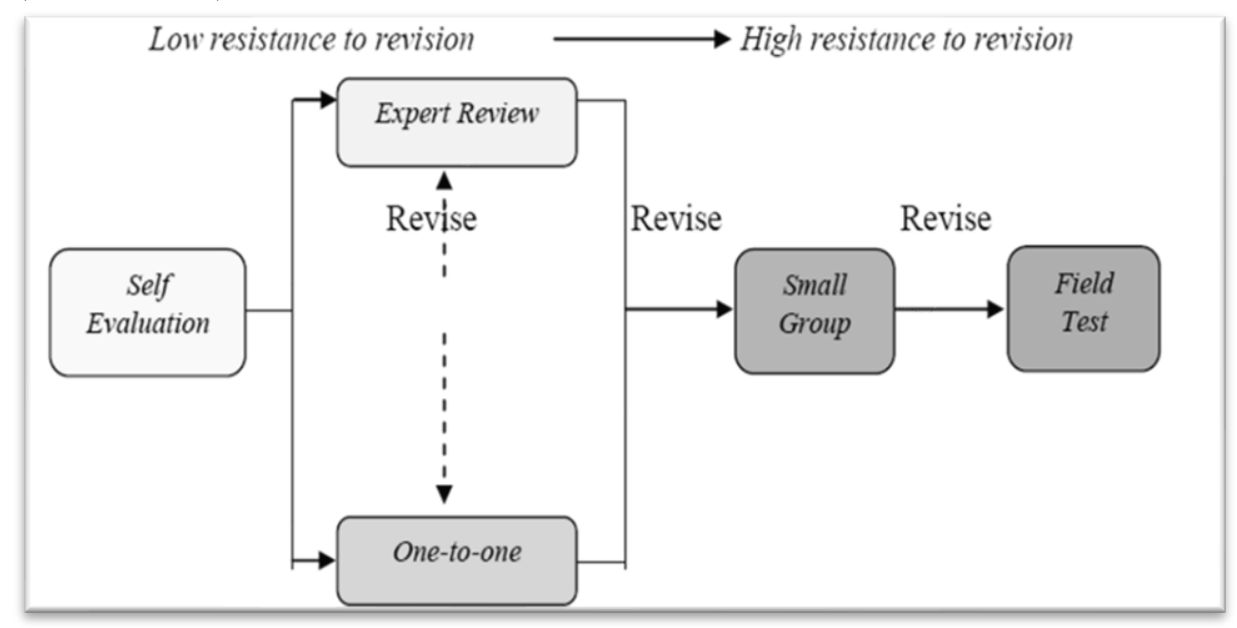

Gambar 1. Model penelitian pengembangan Tessmer (Tessmer, 1998)

Akker dkk. (2007) menjelaskan bahwa model pengembangan Tessmer terdiri atas lima langkah, yaitu sebagai berikut: 1) Evaluasi diri (self evaluation); 2) pendapat pakar (expert review); 3) uji coba perorangan (one to one); 4) uji coba kelompok kecil (small group); dan 5) uji lapangan (field test). Subjek penelitian adalah peserta didik kelas IX SMP Negeri 2 Bati-Bati. Uji perorangan menggunakan sampel 3 orang peserta didik, uji coba kelompok kecil menggunakan sampel 5 orang peserta didik, dan uji coba lapangan menggunakan subjek satu kelas utuh berjumlah 27 orang peserta didik.

Penelitian ini dilaksanakan selama beberapa kali pertemuan dengan tujuan melihat efektivitas perangkat pembelajaran yang dikembangkan untuk melatihkan keteremapilan berpikir kritis peserta didik. Teknik pengumpulan data dilakukan melalui observasi, dokumentasi, dan tes untuk mengetahui keefektifan dari perangkat pembelajaran yang dikembangkan. Tes tertulis digunakan untuk menilai peningkatan kemampuan berpikir kritis peserta didik. Teknik analisi data yang digunakan dalam penelitian ini adalah analisis kuantitatif untuk melihat efektivitas perangkat pembelajaran yang dikembangkan.

\section{HASIL DAN PEMBAHASAN}

Perangkat pembelajaran yang dikembangkan akan dikategorikan efektif apabila perangkat tersebut mampu mencapai tujuan penelitian atau memiliki nilai lebih atau nilai tambah dari perangkat pembelajaran yang telah ada sebelumnya. Perangkat berpikir kritis yang dikembangkan menggunakan model discovery learning dan merupakan adaptasi dari indikator berpikir kritis milik Watson-Glaser (Watson \& Glaser, 2012). Peneliti mengadaptasi lima indikator dengan melalukan percobaan sederhana untuk menilai suatu kesimpulan dengan alasan yang disertai data logis.

Indikator pertama dari berpikir kritis adalah inferensi yang merupakan kegiatan peserta didik untuk menilai dan menganalisis benar atau salah pernyataan yang diberikan yaitu berupa kesimpulan. Indikator kedua adalah rekognisi asumsi, ditahap ini peserta didik mengidentifikasi pernyataan atau masalah-masalah yang relevan, guru membantu mengarahkan peserta didik dalam analogi dan deskripsi secara kritis dari berbagai sudut pandang. Indikator ketiga adalah deduksi yang menghadirkan kesimpulan awal. Indikator keempat adalah interpretasi yang mengharuskan peserta didik menilai bukti-bukti atau informasi yang diberikan untuk memutuskan apakah kesimpulan berdasarkan data terjamin kebenarannya. Indikator kelima adalah evaluasi argumen, dalam tahap ini peserta didik mengevaluasi kekuatan dan relevansi argumen sehubungan dengan pertanyaan atau masalah tertentu. Hasil 
Putri, M.H., Fahmi., \& Wahyuningsih, E. (2021). Efektivitas Perangkat Pembelajaran IPA untuk Melatihkan Keterampilan Berpikir Kritis Peserta Didik SMP pada Materi Pokok Listrik Statis.

keterampilan berpikir kritis kelima indikator pada uji lapangan selama lima kali pertemuan dapat dilihat pada Gambar 2 berikut.

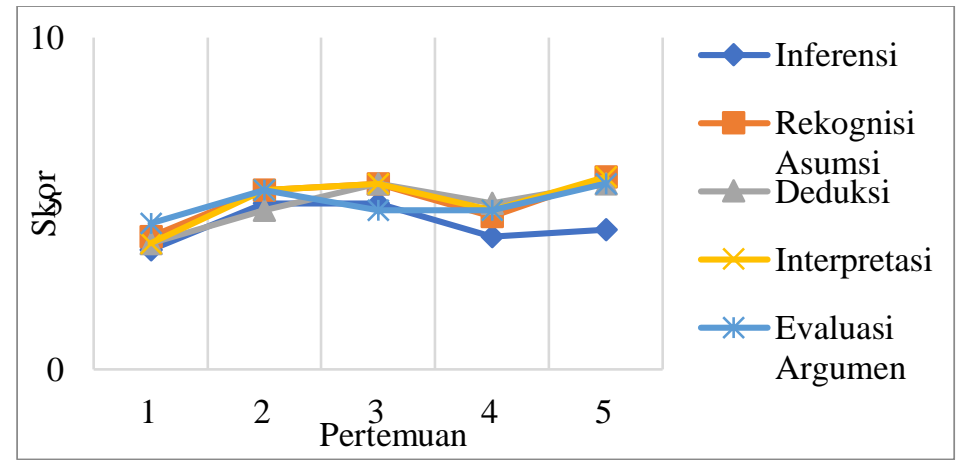

Gambar 2. Hasil keterampilan berpikir kritis uji lapangan

Berdasarkan penilaian keterampilan berpikir kritis yang dilakukan selama uji lapangan pada indikator inferensi terjadi tren penurunan pada pertemuan keempat pada sebagian besar kelompok. Ada kemungkinan peserta didik mengalami kesulitan dalam memahami soal pada indikator ini khususnya pada LKPD 4. Perubahan yang tidak terlalu signifikan pada indikator inferensi dikarenakan peserta didik masih sering menentukan pernyataan atau kesimpulan yang diberikan selalu benar, namun mengabaikan informasi data bersifat logis ataukah tidak. Permasalahan ini dapat diatasi dengan melakukan apersepsi dan organisasi diawal kegiatan pembelajaran dengan menekankan hubungan pembelajaran dengan lingkungan dikehidupan sehari-hari, sehingga peserta didik memiliki kesiapan pengetahuan yang baik terhadap pembelajaran yang akan berlangsung ditunjang dengan literasi yang dimiliki.

Hasil penilaian indikator rekognisi asumsi menunjukkan tren peningkatan pada sebagian besar kelompok, bahkan ada empat kelompok yang mendapat skor maksimal. Peserta didik relatif mudah dalam menilai suatu argumen logis dengan memberikan alasannya dan benar secara kesimpulannya, hal ini juga sejalan dengan hasil penelitian Setiadi (2018) yang juga menunjukkan kecenderungan yang sama.

Pada indikator deduksi didapat hasil yang baik dan beragam. Semua kelompok mengalami tren peningkatan. Kemampuan peserta didik dalam menarik suatu kesimpulan berdasarkan informasi yang diberikan dapat dikatakan baik, walaupun masih perlu ditingkatkan lagi. Hal serupa juga terjadi pada hasil penilaian dari indikator interpretasi mengalami tren peningkatan untuk semua kelompok. Peningkatan keterampilan ini ditandai patuhnya peserta didik dalam menjalankan instruksi, peserta didik sudah mampu menafsirkan suatu kesimpulan berdasarkan informasi yang diberikan dan mengabaikan pengetahuan umumnya namun harus tetap logis. Fahmi (2018) dalam penelitiannya menyebutkan bahwa kemampuan menafsirkan suatu permasalahan menjadi salah satu penyebab meningkatnya level berpikir peserta didik.

Hasil keterampilan berpikir kritis pada indikator evaluasi argumen uji lapangan sudah baik, karena mengalami mengalami tren peningkatan pada beberapa kelompok. Hal ini yang ditandai dengan sebagaian besar kelompok peserta didik telah mampu memberikan alasan yang benar, mengindikasikan bahwa peserta didik bisa membedakan argumen yang berhubungan langsung maupun tidak dengan isi kesimpulan. Fahmi dkk., (2019) menyebutkan bahwa peserta didik dapat dikatakan berpikir kritis jika mampu memberikan argumentasi yang rasional dalam suatu permasalahan.

Hasil belajar pada uji lapangan menunjukkan bahwa dari 27 peserta didik yang belum memenuhi ketuntasan nilai minimal pada mata pelajaran IPA ada 7 peserta didik sedangkan yang sudah tuntas dengan nilai $\geq 70$ ada 20 peserta didik. Secara keseluruhan nilai peserta didik sudah baik, lebih dari separuh jumlah peserta didik di kelas IX mendapat hasil belajar yang tuntas, sehingga dikatakan perangkat pembelajaran yang dikembangkan dapat diterapkan selama proses pembelajaran. Berdasarkan hasil observasi keseluruhan pada uji lapangan menunjukkan hasil yang baik.

Penggunaan perangkat pembelajaran yang dikembangkan dinilai berjalan dengan baik. Guru maupun peserta didik dinilai cukup nyaman dalam menggunakan perangkat yang di dalam pelaksanaannya perlu keaktifan dan komunikasi yang intens. Adapun dalam melatihkan keterampilan berpikir kritis terdapat peningkatan yang cukup baik, hal ini dapat terlihat dari hasil berpikir kritis peserta didik yang tidak berada pada nilai minimum dan dapat menandakan bahwa proses berpikir kritis bisa dinilai melalui alasan 
tertulis. Hasil ini menggambarkan bahwa perangkat pembelajaran berpikir kritis yang dikembangkan bisa digunakan di lapangan secara utuh di kelas nyata atau dengan kata lain perangkat yang dikembangkan dapat dikategorikan efektif. Zaini dan Supiati (2017); Hariati dkk. (2020) menyatakan bahwa peningkatan kemampuan berpikir kritis peserta didik yang terlihat dalam pembelajaran menjadi salah satu keefektifan suatu perangkat pembelajaran.

\section{SIMPULAN}

Perangkat pembelajaran yang dikembangkan dengan mengadaptasi indikator berpikir kritis Watson-Gleser terbukti efektif untuk melatihkan keterampilan berpikir kritis peserta didik. Hasil ini menunjukkan bahwa penelitian pengembangan seperti ini penting untuk terus dilakukan, sehingga peningkatan pengetahuan dan keterampilan peserta didik bisa terus berlanjut, dan berdampak besar bagi Bangsa Indonesia dalam menyongsong persaingan global yang telah terjadi dan dimasa yang akan datang.

\section{DAFTAR PUSTAKA}

Af'idayani, N., Setiadi, I., \& Fahmi. (2018). The Effect of Inquiry Model on Science Process Skills and Learning Outcomes. European Journal of Education Studies, 4 (12), 177-182. Doi: 10.5281/zenodo.1344846.

Akker, J, V., Bannan, B., Anthony, E., Kelly., Nieveen, N., \& Plomp, T. (2007). An Introduction to Education Design Research. Prosseding of the Seminar Conducted at the East China Normal University. Shanghai (PR China), November 23-26, 2007. Enshede the Netherlands: Netzodruk, Enschede.

Arianda, N. (2018). The Effects of Discovery Learning Model Nuanced Science Literacy Towards Students' Competence in Learning Natural Science. International Journal of Progressive Sciences and Technologies (IJPSAT) 8 (1). ISSN: 2509-0119. http://ijpsat.ijsht-journals.org.

Chang, Shu-Nu \& Chiu, Mei-Hung. (2005). The Development of Authentic Assessments to Investigate Ninth Graders' Scientific Literacy: In the Case of Scientific Cognition Concerning the Concepts of Chemistry and Physics. International Journal of Science and Mathematics Education. 10 (3), 117140 .

Fahmi \& Irhasyuarna, Y. (2019). Pengantar Pendidikan: Manusia, Pendidikan, dan Perkembangan Zaman. Banjarmasin: Program Studi Magister Keguruan IPA PPs ULM.

Fahmi., Setiadi, I., Elmawati, D., \& Sunardi. (2019). Discovery Learning Method for Training Critical Thinking Skills of Students. European Journal of Education Studies, 6 (3), 342-351. Doi: 10.5281/zenodo.3345924.

Fahmi. (2018). Pengembangan Perangkat Pembelajaran untuk Melatihkan Keterampilan Berpikir Kritis Peserta Didik SMP pada Materi Klasifikasi Benda. Tesis. Program Studi Magister Keguruan IPA PPs ULM.

Hartati, M., Zaini, M ., \& Kaspul. (2020). The Effectiveness of High School Biology Students Worksheets Based on Critical Thinking Skills on the Protist Concept. BIO-INOVED: Jurnal Biologi-Inovasi Pendidikan, 2 (1), 1-6.

Khabibah, E.N. (2017). The Effectiveness of Module Based on Discovery Learning to Increase Generic Science Skills. Journal of Education and Learning. 11 (2), 146-153. Doi: 10.11591/edulearn.v11i2.6076.

Khaerani, S.K., Utami, S.D., \& Mursali, S. (2020). Pengembangan Perangkat Pembelajaran IPA Berbasis Kearifan Lokal untuk Meningkatkan Hasil Belajar Kognitif Siswa. Journal of Banua Science Education (JBSE), 1 (1), 35-42. E- ISSN: 2745-7222. Doi: 10.20527/jbse.v1i1.2. http://jbse.ulm.ac.id/index.php/JBSE/issue/view/2

Marie, F.D \& Emmanuelle, A. (2011). Philosophy, Critical Thinking and Philosophy for Children. Educational Philosophy and Theory. 43 (5).

Kemndikbud. (2019). Pendidikan di Indonesia: Belajar dari Hasil PISA 2018. Jakarta: Pusat Penilaian Pendidikan Balitbang Kemendikbud.

Ningtyas, T.R., Susilowati, E., Suyidno., \& Zainuddin. (2020). Desain Perangkat Pembelajaran Kooperatif Berbasis Eksperimen untuk Meningkatkan Tanggung Jawab dan Pemahaman Konsep Peserta didik dalam Pembelajaran Fisika. Journal of Banua Science Education (JBSE), 1 (1), 43-50. E- ISSN: 2745-7222. Doi: 10.20527/jbse.v1i1.y. http://jbse.ulm.ac.id/index.php/JBSE/issue/view/2 
Putri, M.H., Fahmi., \& Wahyuningsih, E. (2021). Efektivitas Perangkat Pembelajaran IPA untuk Melatihkan Keterampilan Berpikir Kritis Peserta Didik SMP pada Materi Pokok Listrik Statis.

Rahayu, A.B., Hadi, S., Istyadji, M., Zaini, M., Sholahuddin, A., \& Fahmi. (2018). Development of Guided Inquiry Based Learning Devices to Improve Student Learning Outcomes in Science Materials in Middle School. European Journal of Alternative Education Studies, 3 (2), 107-117. Doi: 10.5281/zenodo.2261027.

Rahmawati, I., Mastuang., Suyidno., \& Sunarti, T. (2020). Kelayakan Bahan Ajar Elastisitas dan Hukum Hooke Berbasis Inkuiri Terbimbing untuk Melatihkan Keterampilan Proses Sains Peserta Didik. Journal of Banua Science Education (JBSE), 1 (1), 21-28. E- ISSN: 2745-7222. Doi: 10.20527/jbse.v1i1.1. http://jbse.ulm.ac.id/index.php/JBSE/issue/view/2

Setiadi, I. (2018). Pengembangan Perangkat Pembelajaran IPA SMP untuk Melatihkan Keterampilan Berpikir Kritis pada Topik Interaksi Makhluk Hidup dan Lingkungannya. Tesis. Program Studi Magister Keguruan IPA PPs ULM.

Tessmer, M. (1998). Planning and Conducting Formative Evaluation. London: Kogan Page.

Watson, G \& Glaser, E.M. (2012). Watson-Glaser Critical Thinking Appraisal: User-Guide and Technical Manual, UK Supervised and Unsupervised Versions 2012. Pearson Education Ltd.

Zaini, M \& Supiati. (2017). Developing Learning Device on Environment Pollution Topic in Senior High School. The Social Sciences, Medwell Journal Scientific Research Publishing Company (in Press). Article number 31887-TSS. 